\title{
A NEGYEDIK IPARI FORRADALOM DIGITÁLIS ÚJÍTÁSAI - ÁLLAPOTFIGYELŐ-KARBANTARTÓ RENDSZEREK HATÁSA A TERMELÉKENYSÉGRE
}

\author{
Digital Innovations of the Fourth Industrial Revolution - The \\ Impact of Condition Monitoring Systems on Productivity
}

\section{Gyüre Ferenc ${ }^{1}$}

\begin{abstract}
Absztrakt: A negyedik ipari forradalom és a digitalizáció komoly mértékű versenyképesség növekedést jelent a vállalkozások számára. A digitalizáció minden területre kihat, így nincs ez másképpen sem a karbantartásra sem, ahol új fajta karbantartás-rendszere, állapotfigyelő-szolgáltatások jelentek meg a digitalizáció hatására, melynek eredményeképpen drasztikus karbantartási megtakarítások, álló idő csökkenések, raktározási kiadások csökkenése várható, és jelentős termelékenység növekedés várható. Az új rendszer új stratégiai irányokat is felvet, melyre a közeljövőben a vállalkozási menedzsmentnek fel kell készülnie, és megfelelő módon kell implementálni a cég mûködésébe. Sajnos nagyon kevés adat és információ áll még rendelkezésre ennek az új rendszernek a müködéséről, azonban az a kevés, ami fellelhető igen kecsegető eredményekkel, és bizakodásra okot adó körülményeket vázol fel.
\end{abstract}

Kulcsszavak: karbantartás, állapotfigyelő-karbantartás, digitalizáció, negyedik ipari forradalom, ipar 4.0

Abstract: The Fourth Industrial Revolution and digitalisation mean a significant increase in the competitiveness of businesses. Digitization affects all areas, so it is no different for maintenance, where new types of maintenance systems, condition monitoring services have emerged as a

1 Gyüre Ferenc, Debreceni Egyetem, Gazdaságtudományi Kar, Ihrig Károly Doktori Iskola. Debreceni Egyetem, Közgazdasági Igazgatóság, Költségvetési osztály. E-mail címe: ferenc.gyure@gmail.com.

A szerző további munkásságát lásd a Magyar Tudományos Művek Tárában: https: $/ / \mathrm{m} 2 . \mathrm{mtmt}$. hu $/$ gui2 $/$ ?type $=$ authors\&mode=browse\&sel $=10070662$ 
result of digitization, resulting in drastic maintenance savings, reduced downtime, reduced storage costs, and significant productivity gains. expected. The new system also raises new strategic directions, which the business management must be prepared for in the near future and properly implemented in the operation of the company. Unfortunately, very little data and information is still available on how this new system works, but there is little that can be found with very promising results and outlines circumstances that are encouraging.

Keywords: maintenance; statemonitor-maintenance; digitalisation; industrial; industry 4.0

\section{BEVEZETÉS}

A tanulmányomban a digitalizációnak és a vállalati termelékenységnek a kapcsolatát vizsgálom a karbantartás modernizációjának a tükrében. A 2020-as évben bekövetkező pandémia szinte minden országban felgyorsította a digitalizálós folyamatot, mely számos esetben új kihívásokat és új eredményeket teremtett a vállalkozások életébe. Az Ernst and Young (a továbbiakban: EY) 2020-as tanulmányában kifejti, hogy a vállalkozások számára a pandémia következtében dönteniük kell arról, hogy milyen digitális stratégiát alakítanak ki akár szolgáltatásról akár a vállalkozáson belüli eszközök felhasználásáról legyen szó. Nem elég csak a digitális térben megjelenni, hanem digitálissá is kell válni. A digitális térben keletkezett adatok elemzésére több mint 5 millió dollárt költöttek a globális vállalatok. Pölös ${ }^{3}$ cikkében kiemeli, hogy a több mint 2500 megkérdezett cég 79\%-a emelte meg a digitalizációra szánt éves keretösszegét. A pandémia nélkül a 2020-ban elért fejlődési ütemet hat év alatt valósította volna meg a világ. A vállalati vezetôk 34\%-a pedig meg sem próbál a válság előtti vállalati struktúrára visszaállni.

A vállalatok digitalizációját segítő startup cégekre igen jelentős feladat hárul tehát, hogy sikerrel segítsék a környező vállalatokat. Az Innosight Consulting $^{4}$ cég előrejelzései szerint az S\&P500 részvénypiac cégösszeállítása 2026-ra teljesen meg fog változni. A most sikeres

${ }^{2} \mathrm{EY}, 2020$.

3 PÖLÖS, 2020.

4 INNOSIGHT, 2020. 
vállalkozásokat felváltják az új startup cégek, és a gyorsan reagáló digitálissá vált vállalatok.

A digitális vállalkozás termelékenysége - vállalkozástól függően gyakorlatilag bármilyen mértékben és bármeddig növekedhet. Erre az EY 2020-as tanulmánya is rávilágít. Gyakorlatilag megvalósulhatnak olyan vállalkozási munkafolyamatok is, melyek a hét mind a hét napján 0-24 órában múködnek. Ehhez gyakorlati példaként hadd említsem, hogy Amerikában több mint 1,3 millió főnek van teherautóra vonatkozó vezetői engedélye, azonban már számos teszten sikeresen alkalmazták a teherautóvezető automatikát, mely előre beprogramozott útvonalon önvezető módon közlekedik. Vagy említhetem a Bosch Global gyárát, mely egy állandóan online térben lévő, öntanuló, folyamatosan programozható gyártósor, melynek bármilyen része távolról bármikor változtatható az online kapcsolat miatt. Sajnos ez természetesen magával hordozza a munkavállalók helyzetének kérdését, hiszen a digitális térben növelt hatékonyság és termelékenység a fizikai dolgozók hátrányára történik. Ennek megoldása az lehet Glavanits ${ }^{5}$ szerint, hogy a munkavállalókkal tisztázzák a digitális kornak ezt a hátrányát, és ösztönzik, támogatják a dolgozókat az átképzésre, továbbképzésre. Kornai ${ }^{6}$ szerint a továbbképzésben elsajátított tudásanyag sikeresen felhasználható a továbbfoglalkoztatásra, hiszen a vállalkozás digitalizációja mellett az igazi tőke a tudás.

A tanulmányom/cikkem felépítése során bemutatom, hogy mi is a 4 . ipari forradalom, a digitalizáció, és a vállalati termelékenység. Továbbá megvizsgálom, hogy mi a különbség az ipari forradalom és a digitalizáció között, mivel számos esetben a két fogalmat szinonimaként emlegetjük, azonban a mögöttes tartalma nem egyezik meg. Továbbá egy rövid részben ismertetem, hogy milyen lehetőségek tárulhatnak egy-egy digitális szolgáltatást végző vállalkozás elé, amennyiben nemzetközi szinten próbál érvényesülni.

A tanulmány ezen szakasza után pedig szakirodalomban bemutatott eredmények alapján - azt szintetizálva - fogom szemléltetni, hogy milyen gazdasági hatásai vannak a 4. ipari forradalomnak a karbantartásra, valamint a megújult karbantartási megoldásnak az állapotfigyelő-szolgáltatásnak a vállalkozás termelékenységére. Sajnos nagyon kevés cég alkalmazza ezt a rendszert, melyek közül nem találtam egyet sem, akik meg is osztanák a

\footnotetext{
${ }^{5}$ GLAVANITS, 2018. 323. o.
}

${ }^{6}$ KORNAI, 2018. 909.o. 
gyakorlati eredményt számadatokban, így az egyes tanulmányok elemzéseire és eredményeire tudok támaszkodni, és abból tudok következtetést levonni. Természetesen felhasználom a már meglévő beszámolókat, cégelemzéseket is.

\section{SZAKIRODALMI ÁTTEKINTÉS}

\subsection{Negyedik ipari forradalom}

A 4. ipari forradalom (Ipar 4.0) lehetőséget teremt arra, hogy a termelési szektor teljesen digitálissá váljon, a használatban lévő gépek kapcsolatban legyenek egymással. Nem azért mert eddig számos új technológia jelent meg a világban, hanem mert kialakultak olyan hálózati rendszerek $(4 G, 5 G)$ melyek élő adatokat szolgáltatnak, és megteremtik az esélyt a gépek azonnali kommunikációjára. Tehát a negyedik ipari forradalom a gép-gép és a gép-ember közötti kommunikációt helyezik át digitális térbe, elősegítve a gyors reagálást, a pontosabb munkavégzést, nagyobb termelékenységet, kevesebb hibalehetőséget.

A negyedik ipari forradalom számos tanulmányt, ennek következményeként számos definíciót is jelent.

Kagermann ${ }^{7}$ - A rendelkezésre álló erőforrásoknak, információknak, technológiáknak olyan hasznosítása, mely robbanásszerū fejődést eredményez, eredményezhet a termelési szektorban.

Liu $^{8}$ - A termelési szektorban lévő adatok gyűjtése, feldolgozása, döntéselőkészítése és döntéstámogatása úgy, hogy a rossz döntéseket kizárja algoritmusok felhasználásával. Ezzel egy azonnali kapcsolati hidat képezve a termelés és a döntés között, mely teljes egészében megváltoztathatja a vállalkozások működését.

Schumacher és $\operatorname{Sihn}^{9}$ - A 4. ipari forradalom nem más, mint a vállalkozás értékteremtő folyamatának teljes digitális, adatokkal teli nyomkövetése, elemzése, feldolgozása.

Schwab $^{10}$ - A technológiának teljesen újszerű használata, melynek segítségével a gyárak, gazdaságok, kormányzati döntések teljesen új

\footnotetext{
${ }^{7}$ KAGERMANN, 2013.

${ }^{8}$ LIU, 2016. 173.o.

${ }^{9}$ SCHUMACER - SHIN, 2016. 161.o.

10 SCHWAB, 2016.
} 
értelemben jelennek meg. Az ipari forradalom hatása nem mutatható ki csak egy vállalkozásnál, hanem globális hatása van.

Wang $^{11}$ - A teljes termelési technológiák azonnali egységesítését lehetôvé tévő digitalizáció, melynek során a globális problémákra is választ kapunk/kaphatunk.

A fogalmi meghatározások során mindenki kivétel nélkül a vállalkozásokra generált hatást mutatta, vagy emelte ki. A másik figyelemre méltó szinte állandó szóhasználat a technológia és hatása szavak. Ezek alapján, ha minden fogalmat egybe akarnánk rakni, és emészthetôvé szeretnénk tenni, akkor azt tudnám ezek alapján megfogalmazni, hogy: „A 4. ipari forradalom egy olyan uj technológiai újitásokekal rendelkeezó" informatikai, gazdasági, társadalmi jelenség, melynek segitségével és következtében az alapvetö termelési, szolgáltatási folyamatok, szociális kapcsolatok teljes digitalizációja, automatizációja figyelhetó meg, melynek eredménye, egy gyors, mindenre reagáló globális automata rendszer."

A negyedik ipari forradalom az élet és a gazdaság számos területére hatást gyakorol. Kusmin ${ }^{12}$ szerint rohamos mértékben fejlődött és fejlődik az információs és kommunikációs technológia, a virtuális-fizikai valóság határának elmosódása a termelés területén, a hálózati kapcsolati pontok és kapcsolódási lehetőségek robbanásszerû növekedése, a big data előretörése, a felhőalapú tárolási rendszerek térnyerése, a modellezés-szimuláció valósághú reprodukálása, valamint az ember-robot kapcsolatának megjelenése.

Az információs és kommunikációs technológia rendkívüli előretörést hozott el mind a termelés-értékeremtési folyamat, mind a szociális háló terén. Lehetôvé tette azt, hogy egy gyártási folyamat során minden adat digitálisan is elérhetővé váljon úgy, hogy minden részleg/vezetési szint a számára fontos információt megfelelően strukturálva láthassa, használhassa, így akár menetközben reagálva egy-egy hibára. Ez magával hozza a modellezést és a szimulációs programok térnyerését, amelyet a modern gyárakban a termeléssel párhuzamosan folytatnak le, így akár termelés közben lehet változtatni a terméken/szolgáltatáson és annak tulajdonságain. Továbbá a termelés és szolgáltatás nyújtás során, a folyamat közben akár egy-egy problémát előre is lehet jelezni. Természetesen ez a hatalmas szimulációs adat és egyéb információs bázis olyan mértékű tárhelyet

\footnotetext{
11 WANG, 2016. 358.o.

12 KUSMINM, 2019.
} 
igényelnek, hogy hagyományos számítógépek tároló kapacitása azt már nem tudná kezelni, így az internet alapú felhő szolgáltatások is elterjedtek. Így lehetôség van bármilyen mértékű adatot interneten, felhőben tárolni és bárhonnan hozzáférni, több platformon is egyszerre. De ezen adathalmazoknak nem csak a tárolása problémás, hanem a feldolgozása is. Ezen a ponton érkeztünk meg a Big Data felhasználására, melyre külön programok és gépek kellenek a folyamatos és pontos adatfeldolgozásért, mely indokolja a robotika bevezetése, hiszen a folyamatosan növekvő adathalmazt már csak egy öntanuló mesterséges intelligencia képes kezelni. Ez a teljes komplex kör pedig lehetőéve tette a teljesen digitális és robotok által múködtetett gyárak létrehozását. ${ }^{13} 14$

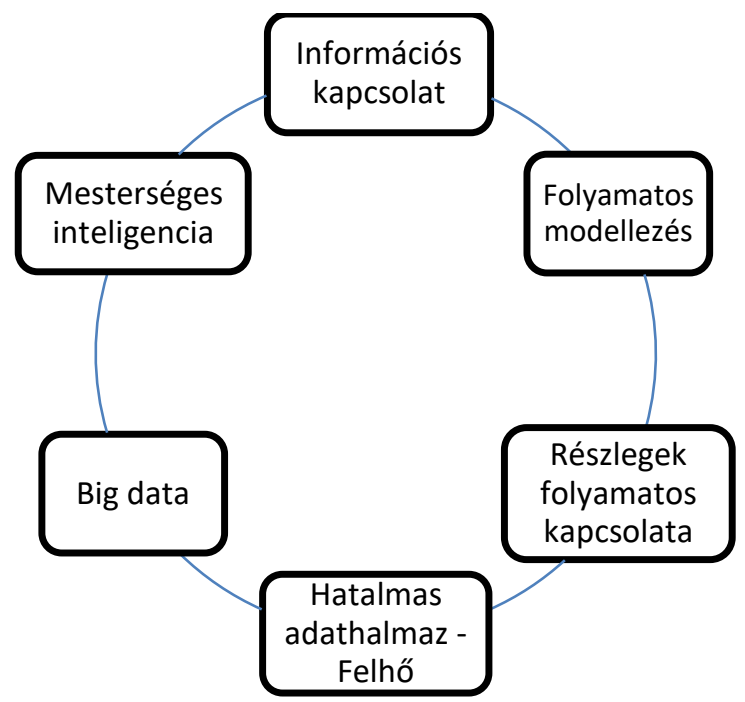

1. ábra: Industry 4.0 folyamata egy termelés során. Forrás: Saját szerkesztés Kusmin alapján. ${ }^{15}$

\subsection{Az ipari forradalom előnyei}

Amennyiben egy termelési szektort veszünk alapul, akkor azt mondhatjuk, hogy a 4. ipari forradalom megteremti a lehetőséget a hatalmas

\footnotetext{
13 KINZEL, 2019.

14 DAVIES, 2015.

15 KusminM, 2019.
} 
digitális körforgáson keresztül arra, hogy egy olyan termelési és szolgáltatásai folyamat jöjjön létre, mely azonnal képes reagálni minden esetlegesen felmerülő külső és belső problémára. Kerényi ${ }^{16}$ szerint a folyamatos alkalmazkodó készség minden vállalkozás számára jelentős fegyvertény, azonban a reagálási idő és az információ rendelkezésre állása a két legkiemelkedőbb és legfontosabb előnye ennek a forradalomnak egy termelő szektor esetében. De bármilyen szektort figyelembe vehetünk, és azt mondhatjuk, hogy a hatalmas adathalmaz és az öntanuló algoritmusok okán az a legnagyobb előny és fegyvertény a digitálisan nem fejlett versenytársakkal szemben, hogy a változásra azonnal lehet reagálni. A tanulmányban a karbantartásról lesz bővebben szó, és most ennek okán gondoljunk el egy olyan rendszert, mely a cégnél működő összes gépet folyamatosan figyeli, és előre jelzi, hogy melyikkel milyen jellegû probléma lesz/lehet. Képzeljük el, hogy egy ilyen előre jelző rendszer, milyen mértékű előnyt jelenthet, hogy előre jelzi a nagy és kis karbantartást az előtt, hogy szükséges lenne, így kisebb költséggel, de felkészültebben, pontosabban lehet ezeket a karbantartásokat megszervezni.

De a digitalizáció a rugalmas termelési lehetôséget is biztosítja, hogy egy-egy termék igen széles palettáját kínálja egy-egy gyár. A termelés növelése a másik kulcstényezó, hiszen a negyedik ipari forradalomban már robotokkal is el lehet végeztetni egy-egy munkafolyamatot.

\begin{tabular}{|c|c|c|c|c|c|c|c|}
\hline 2012. & 2013. & 2014. & 2015. & 2016. & 2017. & 2018. & 2019. \\
\hline 159 & 178 & 221 & 254 & 304 & 400 & 422 & 381 \\
\hline
\end{tabular}

1. sz. táblázat. Robotok alkalmazásának száma világviszonylatban (1.000 db/év). Forrás: World Robotics alapján saját szerkesztés. ${ }^{17}$

Gyorsabban és hatékonyabban is dolgozik egy robot a tömegtermelésre szánt cikkeknél. Ennek eredménye, hogy így folyamatosan és konstansan magas minőséget tudnak létrehozni a gyárak mindamellett, hogy a hibák és selejtek mértékét csökkentik. A folyamat pedig ott zárul ennek a termelésjavulásnak, hogy így a vevők is elégedettebbek lesznek az adott termékkel, szolgáltatással. Végső soron pedig minden versenyző vállalkozásnak ez a fő célja, a nagyobb vevőelégedettség s így a több árbevétel. A folyamatos adatelemzés, és monitoring pedig lehetôvé teszi azt,

\footnotetext{
${ }^{16}$ KERÉNYI, 2017. 32.o.

17 WORLD ROBOTICS, 2020.
} 
hogy egy azonnali információvezérelt döntési rendszer jöjjön létre, melyet megfelelő robotika azonnal képes lekövetni. A probléma ott kezdődik ilyen esetben, hogy a gépek idővel meghibásodnak, melynek rengeteg következménye van költség oldalról. Álló idő, javítási költség addig a termékeket raktározni kell, melyhez raktározási költség társul. Ennek megoldásaként és kiküszöböléseként alakult ki a karbantartási-szolgáltatás, állapotfigyelő-rendszer, mely folyamatosan elemzi a gépeket és jelzi az esetleges jövőben várható hibákat. Valamint a meglévő egyéb gépekhez és termékekhez kapcsolód adatokat rendszerezi, elemzi. A negyedik ipari forradalomban megvalósuló automatikus karbantartás-figyelő rendszert nagyon kevés cég használja napi szinten a termelésében. A GE cégcsoport, valamint az SKF vállalat a múködésük során ennek bevezetésére komoly hangsúlyt fektettek. A saját belső kutatási eredményeik szerint a karbantartás figyelő rendszer, lehetőséget teremt arra, hogy a gépek egymás közötti együttműködésük hatékonyabb, átláthatóbb legyen, továbbá az a szolgáltatás a gépek technikai támogatását könnyebbé tegye, valamint a menedzsment részéről a pontosabb információk eredményeként decentralizáltabb döntéseket szülessenek. A cégek beszámolói és a Six Sigma elemzése alapján egy ilyen rendszer bevezetése több részből áll. Szükséges hozzá információtechnológiai kiadás, szakmai segítség, oktatás, adatelemzés, szoftverek, hardverek. A becslések szerint ${ }^{18} 420$ ezer dollár körül lehet egy ilyen rendszert bevezetni, azonban vállalati szempontból rengeteg munkaóra kell, hogy pontosan használják a rendszert és elkezdjen megtérülést generálni.

A rendszer előnye, hogy a hibák előrejelzése során jelentősen csökkenthető a termelés során a selejt termékek aránya, melynek közvetlen és közvetett hatása van a gépek eredményére és a raktározási költségekre. Szűcs ${ }^{19}$ szerint egy-egy hiba előrejelzés nem csak egy prediktív folyamat, hanem egy múltba tekintő lehetôség is, hiszen a rendszer képes a hibák nyomon követésére, mely minőségbiztosítás szempontjából a vizsgálatok gyorsabban, hatékonyabban és gazdaságosabban hajthatóak végre.

\footnotetext{
18 Six Sigma, 2020.

19 SZÜCS, 2011. 106.o.
} 


\subsection{Digitalizáció}

Az 1990-es évektől elindult egy folyamat, mely közel 30 éven át fejlődött. Ez a folyamat a digitalizáció volt, melyben számos technológiai újítás jelent meg, mely minden területre hatalmas hatást fejtett ki. Az információ teljes terjedelmében azonnal rendelkezésre állhat bárki számára. A számítógépek kapacitásnövekedése lehetőséget teremtett bonyolult adatok feldolgozására és könnyebbé tette a hatalmas adathalmazok kezelését. Minden informatikai és technológiai vívmány lehetôséget teremtett, hogy mai kort éljük, és ezt úgy nevezzük, hogy digitális transzformáció. ${ }^{20}$

Csedő, Máté, Sára ${ }^{21}$ szerint a digitalizáció, mint fogalom a folyamatok, tartalmak digitálissá válását jelenti, melyek korábban, vagy elsődlegesen fizikailag álltak rendelkezésünkre. Ennek továbbfejlődése a digitális transzformáció, mely a komplex változást jelent, ami hatással van egy-egy szervezet múködésére. A transzformáció vállalati szempontból egy új képességbe, folyamatban, eljárásba való befektetést jelenti, mely valamilyen erőforrást követel és eredményként egy újrakombinált, újfajta folyamat születik, vélhetően magasabb hozzáadott értéken.

Monostori $^{22}$ és $\mathrm{Xue}^{23}$ szerint a negyedik ipari forradalom és a digitalizáció között nehéz határvonalat meghúzni, és szerinte csak annyi különbözteti meg a két fogalmat a termék elóállitása és a szolgáltatás nyújtásának folyamatában, hogy a negyedik ipari forradalom elvén működő okos gyárak forradalmian újultak meg, míg a digitalizációt csak a szükséges mértékben használó versenytársak csak fejlettebbek lettek. Ez roppant bonyolult megfogalmazást állít elénk, melyet meg is magyaráz Monostori. Az ipari forradalomban élenjáró vállalatok és a digitalizált vállalatok is ugyan azt a rendszert használják, ugyan azok a feltételek állnak rendelkezésükre. A különbség abból adódik, hogy negyedik ipari forradalom hatására ezek a rendszerek a teljes összekapcsolódás és folyamatos kommunikáció szintjéig egyszerre dolgoznak közösen, míg a digitalizációt csak felhasználó vállalatok csupán különállóan, önmagukban használják a rendszereket. A különbség a kapcsolat. Így a folyamatosan kapcsolatban álló termelési rendszerek és szintek lehetőséget teremtenek arra, hogy azonnal reagáljanak a hibákra, így

\footnotetext{
${ }^{20}$ MugGe, 2017.

${ }^{21}$ CSEDŐ - ZAVARKÓ - SÁRA, 2019. 7.o.

22 MONOSTORI, 2015. 766.o.

23 XuE, 2020.
} 
minőségileg, forradalmilag újuljanak meg, míg a digitalizált vállalatok ugyan használják az újításokat, de nem olyan szorosan vannak összekapcsolva, így ők az átlagos vállalatoktól fejlettebbek, de nem forradalmiak.

Mindkét fogalom a vállalati termelésre és szolgáltatásnyújtásra vonatkozik, azonban az új 4. ipari forradalmi technológiák a vállalkozás külső és belsô rendszereire is hatnak, beépülnek az értékteremtő folyamatba, és a teljes értékláncot változtatják jövedelmezőbbé, míg a digitalizáció, csak az értékteremtés egy-egy szintjére hat.

Hagyományosan a vállalkozásoknak folyamatosan fejlődniük kell, hogy a sikeres múködésük a továbbiakban is megalapozott legyen. A fókuszpontjukban a profitorientált vállalkozásoknak a termelés fokozása és a termékek értékesítése áll. Az innovációs tevékenységük alapjait ez a két tényező határozza meg alapvetően Herterich, Uembernickel és Brenner szerint. ${ }^{24} \mathrm{~A}$ digitalizáció is egyfajta kihívás elé állította és állítja a cégeket, mely abban különbözik a korábbi fejlődési és fejlesztési lehetőségektől, hogy a digitalizáció a vállalkozás teljes egészére hatással van. Példaként lehet említeni, hogy a közösségi média elterjedése „csak” a vállalkozás marketingjét érintette kiemelkedően. Míg maga a digitalizáció hatására megvalósul, hogy a gazdasági szervezet egy sokkal magasabb szintre lépjen és azon teljesítsen.

Kagermann $^{25}$ már többször jelezte digitalizációval foglalkozó tanulmányaiban, hogy a harmadik ipari forradalomban megjelenő kezdetleges gépek elérhetnek egy olyan szintet is, amikor önállóan, csupán gépek kommunikációjával teljesítsenek feladatokat. A negyedik ipari forradalom ezt a korszakot hozta el számunkra. Az új digitalizációs forradalom során az történik, hogy rengeteg számítógépes rendszer múködik összehangoltan. Ez nem jelenti azt, hogy van egy önálló gép, mely mindenek felett áll, hanem a kis számítógépes rendszerek önállóan hálózaton keresztül kommunikálhatnak programkódok segítségével, a hatékonyabb, gyorsabb, pontosabb munkavégzés érdekében. A digitalizáció egy gyár esetében az alábbi ábrával jellemezhető legjobban. Egy olyan folyamatot kapunk a digitalizáció megfelelő felhasználásával kapcsolatban, amely vevőelégedettséget eredményez, ami közvetlenül hat a vállalkozás jövedelmezôségére, valamint a termelékenységre.

${ }^{24}$ Herterich - UEMBERNICKEL - BRENNER, 2015. 323.o.

${ }^{25}$ KAGERMANN, 2013. 


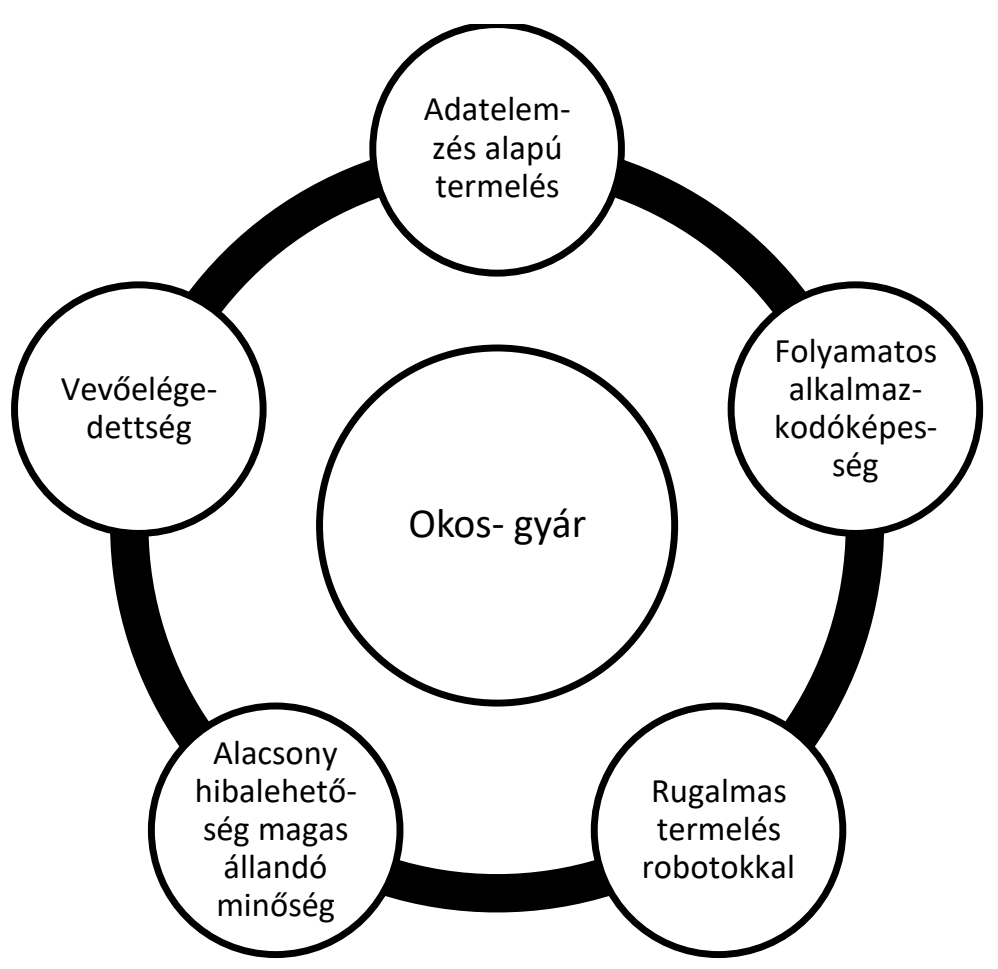

2. sz. ábra. Okosgyár felépítése. Forrás: Saját szerkesztés Mugge alapján. ${ }^{26}$

Korunkban a negyedik ipari forradalom Monostori (2015) szerint egyet jelent az intelligens gyárral. A korábbakban leírtakat ő úgy fogalmazta meg, hogy az ilyen gyárakban a kiber-fizikai rendszereknek a felhasználásával egy sokkal újabb és kedvezőbb gyártási feltételeket alkalmazó termelési sor jön létre. Ezek az új kiber-fizikai rendszerek szerinte a nanotechnológia, lézertechnológia, ipari biotechnológia, 3D nyomtatás, mesterséges intelligencia. Váncza és társai ${ }^{27}$ szerint egy-egy kiber-fizikai rendszer használata a termelő iparban a negyedik ipari forradalom vívmánya, hiszen ez a mögöttes kapcsolat, a folyamatok hátterében lévő, mindent egy rendszerként kezelő „láthatatlan kéz”. Folyamatos visszacsatolást ad a gyártás minőségéről, adatot gyújt a folyamat optimalizálására, alkatrészek

\footnotetext{
26 MugGe, 2017.

27 VÁNCZA ET. AL. 2011. 797.o.
} 
A negyedik ipari forradalom digitális újításai - Állapotfigyelő-karbantartó rendszerek hatása a termelékenységre

műszaki állapotát naplózza, a robotokat logisztikai hatékonyság szempontjából vezeti, a rengeteg adatot naprakészen elemzi.

A korábbiakat összefoglalva három kulcsterületet tudunk kiemelni $\mathrm{Chou}^{28}$ szerint, melyen minden digitalizációs és 4. ipari forradalmi hatás megmutatkozik.

Szervezés - Minden terület az információk birtokában azonnal saját maga javára tudja formálni az adott üzleti modellt, vállalkozási reakciót.

Technológia - Az adtok kezelése, feldolgozása sosem volt ennyire gyors és hatékony. Továbbá a robotok elterjedése és munkavégzése szintén nagyfokú teljesítményrobbanást idéz elő.

Szociális - A kapcsolattartás a különböző hálózati lefedettségek miatt bármilyen távoli területek között megoldható.

\subsection{Termelékenység}

A termelékenység fogalma alatt általános értelemben azt értjük, hogy egységnyi input erőforrás felhasználásával mennyi output/végtermék állítható elő. A Gazdasági Versenyhivatal ${ }^{29}$ saját fogalmi meghatározásában is külön részt szentel a termelékenység körbejárásnak. A termelékenységi mutatókat tehát mindig valami input/output kapcsolatként lehet értelmezni, melyek közül az egyik legjelentősebb mutató a teljes tényezőtermelékenység.

A termelékenység vizsgálatakor szükséges, hogy a hatékonyságot is vizsgáljuk, hiszen a szakirodalmak számos esetben szinonimaként kezelik őket. Azonban a hatékonyságnak a tanulmány szempontjából kettő releváns fajtája van, melyről említést kell tenni. Az egyik a termelési hatékonyság, mely a költségek minimalizálása mellett a legtöbb termék/szolgáltatás előállítását hivatott növelni. A másik a dinamikus hatékonyság, mely az innovációban rejlő potenciális fejlődési képességet mutatja. Ez a fajta képesség képes később termelési hatékonyságban is megmutatkozni.

\subsection{Karbantartási rendszerek}

Az első ipari forradalomtól, vagy mióta gépek léteznek a világon, szükséges, hogy azokat időnként karbantartsák. A gépek elterjedése magával hozta a termelő vállalatokat, amit a technikai újítások tovább fejlesztettek. A

${ }^{28}$ CHOU, 2017. 465.o.

29 GAZDASÁgi VersenyHivatal, 2007. 
gépek modernizációja lehetőséget adott a minél hatékonyabb versenyre a piacon, hiszen minél fejlettebbek lettek a gépek, annál jobb anyagkihozatallal, hatékonysággal dolgoztak. A folyamatos fejlődés pedig a gépek karbantartására is hatással volt. Egyre-másra jelentek meg a modernebb javítási algoritmusok, míg egy teljes vállalati stratégiai szint alakult ki. Zhaofang és társasi ${ }^{30}$ részletezik, hogy a digitális forradalom előtt a karbantartási stratégia az előrejelzésből, megelőzésből és a javításból állt, de ez a 4. ipari forradalomra kiegészült a hibakereséssel. A kutatási eredményük azt mutatta, hogy egy termelő cég esetén - ahol zömmel csak gépekkel dolgoznak - a felmerülő hibák 40-45\%-a kiküszöbölhető lenne, egy megfelelően múködő hibakereső digitális szoftver segítségével. Ehhez arra van szükség, hogy a vállalkozás minden adatát folyamatosan monitorozza egy algoritmus.

\subsection{Nemzetközi hatása a digitalizációnak}

A hatékonyság és termelékenység növekedése kapcsán a vállalati eredményekre gyakorolt hatása megkérdőjelezhetetlen. Ez azt jelenti, hogy egy termelő vállalat szempontjából a megfelelő időben elvégzett karbantartás hatása a költségek oldalán jelentős megtakarítást jelent, míg a folyamatos termelés oldaláról egységnyi erőforrás felhasználásával több termék előállítását teszi lehetôvé. Az érem másik oldalán a karbantartást végző cégek állnak, akiknek így vélhetően többlet bevétele keletkezhet a szolgáltatás nyújtása során. Mindkettő oldalnak végső soron az az eredménye, hogy a vállalkozás által elért jövedelem - minden egyéb tényező változatlansága mellett - növekedik. Lehetôség adódhat terjeszkedni, céget növelni, szolgáltatást kiterjeszteni, telephelyeket létesíteni határon belül és kívül is. Ez pedig azt jelenti, hogy egy-egy digitális megoldás a termelékenység és hatékonyság növelésből adódóan akár a nemzetközi szintérre való kilépést is előidézheti, így szükséges ezen oldal vizsgálata is.

Tehát akár a nemzetközi porondon is történhetnek változások a digitális ipari forradalomnak köszönhetően. A termelékenységnek, hatékonyságnak, vállalati működési attitűd változásnak mind-mind hatása van a nemzetközi politikára is. Most teljesen irreleváns azt vizsgálni, hogy a termelékenység, hatékonyság növekedés minek köszönhető (jobb eljárás,

${ }^{30}$ ZHAOFANG - LeLE - GUANGDONG, 2020. 415.o. 
automatikus karbantartás figyelő szolgáltatás, ipari forradalom). Crabb ${ }^{31}$ megállapította korábbi tanulmányában - véleményem szerint teljesen jogosan -, hogy a nemzetközi politika, diplomácia, vállalati múködés nemzetközi szintre való növelése, két részre bontható. Egyrészről a nemzeti célok kerülnek átültetésre a külpolitikára, azaz, mit szeretne az adott nemzetállam, gazdaság elérni, másrészrôl pedig, hogy maga a szuverén állam, cég, szervezi egység mit ért el már korábban önerőből. Ez azt jelenti a gazdasági nyelvre lefordítva, hogy amennyiben egy adott egységnek van egy olyan tudás a birtokában, melynek eredményeképpen hatása lehet más országgal folytatott gazdasági irányok kialakításába, akkor az az állam „erősebb” és „hatékonyabb” módon tud fellépni érdekeinek érvényesítésében. Továbbá ugyan ez a trend és folyamat figyelhető meg, ha nem nemzetállami, hanem egy vállalati szinten vizsgálódunk.

Cohen $^{32}$ tanulmányában az internet adta lehetôségek alapján tanulmányozta, hogy elérhetünk majd egy olyan korban, ahol a diplomácia, a nemzetközi egyezkedések, vállalati beruházások át költözhetnek a digitális térbe, továbbá ezeknek a külügyi döntéseknek a fő alapjai digitális újítások adta lehetőségek miatt változhatnak. Az már korábban is megvalósult, hogy egy-egy egyeztetés, döntés-előkészítés, tudósítások a digitális világban megvalósuljanak, azonban olyanra még eddig nem volt példa, hogy egy új digitális megoldás miatt lehetôség lehessen új alapokra helyezni a külkereskedelmi gazdasági kapcsolatokat. Ez az újdonság a negyedik ipari forradalomnak köszönhetően valósult meg, mert ezek a digitális újítások olyan szinten képesek egy-egy vállalat vagy akár társadalom múködési attitűdjét, stratégiai beállítottságát megváltoztatni, vagy olyan mértékű erőforrásokat felszabadítani, hogy az adott szervezeti egység nemzetközi kérdésben komoly alkupozicióban legyen.

Lássunk erre egy roppant egyszerú, ám fiktív példát. Adott egy cég, mely csak egy országban tevékenykedik. Tegyük fel, hogy a cikk korábbi részében említett karbantartási szolgáltatást folytatja. A digitális forradalomnak és a gyors reagálásnak köszönhetően versenyelőnyre tesz szert a többi vetélytárssal szemben, és ezt kihasználva - bevételét, befolyását növelve - más országokba is kezdi nyújtani a szolgáltatását. Ez azt jelenti, hogy a negyedik ipari forradalom hatására egy kisebb, főként helyi igényeket kiszolgáló vállalkozás is képes lehet megfelelő előkészületek és további

${ }^{31}$ CRABB, 1972.

32 COHEN, 1998. 
feltételek fennállása esetén nemzetközi szintérre is kilépni. Ezt a fajta mozgásteret természetesen lehetôvé kell tennie a kormányoknak, így értelmet nyer az a korábbi kijelentése Crabbnak, hogy egy külpolitikai irányt az adott nemzet/vállalat által elért eredmények is befolyásolják.

Beata, Manuel, Adnan és Judit ${ }^{33}$ tanulmányukban a digitális ipari forradalom és Magyarország lehetséges növekedési lehetőségeit vizsgálta technológiai újítások szempontjából. A vizsgálatuk során kapcsolatot kerestek a digitális szolgáltatások (pl. automatikus karbantartás szolgáltatás) és a nemzetközi térnyerés között. Az eredmény roppant bíztató, melynek során szignifikáns kapcsolatot találtak a két tényező között. Ezt azzal magyarázták, hogy a jelenlegi új digitális szolgáltatások még nem elterjedtek, így könnyen, nagymértékű piaci részesedést lehet globális szinten megnyerni, amennyiben időben, megfelelő minőségű szolgáltatással lépnek fel a nemzetközi piacra.

A digitális szinten értelmezett nemzetközi kapcsolatok alakítása a negyedik ipari forradalomban már nem csak a kormányok privilégiuma. Manor és Sevege ${ }^{34}$ szerint egy nemzetközi kapcsolt, már a közösségi média szintjén elkezdődik. Egy-egy külföldi államfö, nemzetközi cégek vezetői már különböző platformokon elérhetőek. Lehetőség van a posztokra reagálni, véleményt nyilvánítani, megosztani az eszméket. Ezek mellé továbbá társulhatnak még egyedi, adott személyhez, céghez kötött digitális újítások, melyek hatására az adott ország/vállalat imázsa növekedik.

Hanson $^{35}$ egy átfogó kutatást végzett a negyedik ipari forradalom várható nemzetközi hatásairól, melyek alapján meghatározta, hogy digitális újítások lesznek azok a döntő tényezők, melyek majd a külpolitikai irányokat, gazdasági törekvéseket, a nemzetközi kapcsolatokat és trendeket befolyásolják.

Szintetizálva a korábban említett tanulmányokat, valamint Adesina ${ }^{36}$ cikkét több kulcsterületet határozhatunk meg, melyek a jövőben a negyedik ipari forradalom hatására a nemzetközi kapcsolatokat és döntéseket befolyásolják. Ezek a tényezők alapjaiban változtatják meg a külpolitikáról és diplomáciáról alkotott eddigi elképzelésünket. Alap esetben a külpolitikai elvek szabták eddig a fö irányt, melyeket figyelembe véve alakultak ki a vállalati szintú nemzetközi kapcsolatok. Ez a digitális ipari forradalom

\footnotetext{
33 BEATA - MANUEL - ADNAN - JUDIT, 2020. 1263.o.

34 MANOR - SEGEV, 2015. 89.o.

35 HANSON, 2012. 1.o.

36 ADESINA, 2017.
} 
A negyedik ipari forradalom digitális újításai - Állapotfigyelő-karbantartó rendszerek hatása a termelékenységre

idejére teljesen átalakult, és a digitális újítások közvetett és közvetlen tényezői alakítják ki a külpolitikát, melyek közül a legfontosabbak:

- tudás menedzsment - a társadalom, cégek, vállalatok, egyének birtokában lévő és használható, hasznosítható digitális tudás;

- közösségi háló - az újítások, fejlesztések a közösségi térben bárki számára megtekinthető, tanulmányozható, megismerhető;

- információ menedzsment - a digitális térben fellelhető több adat birtokában, egy külső szemlélő is képes lehet az információkat tanulmányozva a politikai összefüggések megértésében;

- kommunikáció - a digitális térben könnyebben és gyorsabban lehet véleményt cserélni, megosztani, vitákba bekapcsolódni;

- folyamatos erőforrás a tervezésben - végső soron a kormányzat alakítja ki külpolitikai irányvonalakat a továbbiakban is, azonban lehetőségük van a döntések alapján különböző hatásvizsgálatok elvégzésére a megfelelő input adatok bevitelét követően.

A külpolitikai kérdések, nemzetközi kapcsolatok változása a negyedik ipari forradalom hatására nem elhanyagolható sem nemzeti szinten, sem vállalati terjeszkedés szempontjából. Elsődlegesen a külpolitikai irányvonal hatást gyakorol a gazdasági és a politikai területre. A gazdasági vonalon a kereskedelemi politika, beruházási lehetőségek és a pénzügyi és kereskedelmi egyezmények fő irányvonalait is a külpolitika szabja meg. Ezen felül politikai és gazdasági vonatkozás szempontjából az erőforrások áramlása, a nemzetközi együttmúködések és a nemzetközi projektekre való irányvonalat szabja még meg a külpolitika.

Gazdasági szempontból nem elhanyagolható tényező, hogy egy-egy vállalat természetesen a nemzetközi szintéren profitálni is szeretne a digitális újításaiból, mely érezteti hatását nemzeti szinten is. Feder ${ }^{37}$ már korábban megvizsgálta, hogy egy-egy nemzetközi döntés során racionálisabb szempont, ha a gazdasági vonatkozásokat vizsgálják, mint a politikaiakat. Ebből kifolyólag a digitális lehetőség, mely bevételi forrást jelenthet egy nemzetnek, a külpolitikai döntésben jobban érvényre fog jutni, mint egy jobb politikai helyzetet eredményező döntés.

A nemzetközi kapcsolatok vizsgálata szempontjából tehát kulcs tényező az, hogy milyen szolgáltatással, mikor lépnek a piacra. A cikkben említett automatikus karbantartás figyelő szolgáltatás viszonylag új, nagyon kevés helyen használják még. Jellemző, hogy saját vállalkozási körben,

${ }^{37}$ FEDER, 1982. 59.o. 
hatékonyság és termelékenység javitás az elsődleges szempont. Azonban, ha egy ilyen jellegű, vagy hasonló digitális szolgáltatás kiforr, és azzal a nemzetközi színtérre is kilép egy-egy vállalkozás, akkor hatalmas lehetőség tárul elé gazdasági szempontból. A negyedik ipari forradalom hatására eltűnnek a fizikai szolgáltatások hátrányai. A digitális térben folyamatosan jelen lehet lenni a világ bármely pontján, így egy adott digitális szolgáltatás elvégzésére szinte bárki „bejelentkezhet”. Természetesen roppant fontos a megfelelő, konzisztens, magas minőség, hiszen így több vállalat/cég versenyezhet egymással. De a negyedik ipari forradalom egy nemzetközi lendületet is adhat a globális vállalati társadalomnak, melynek hatására véleményem szerint az esetleges nemzetközi vagyoni különbségek is mérséklődhetnek. Természetesen ehhez szükséges egy újfajta vállalati stratégiai szemlélet kialakítása. Ez abban nyilvánulhat meg, hogy egy-egy cég több tevékenység esetén csak eggyel kellene mélyebben foglalkoznia, melynek minőségi jellemzőit a lehető legmagasabb szintre próbálja meg beállítani, és azzal az egy tevékenységgel, szolgáltatással próbál meg a nemzetközi porondra belépni. Véleményem szerint nem szerencsés tapasztalat hiányában több tevékenységre elaprózni a vállalati múködést abban az esetben, ha a nemzetközi térre való kilépés a cél, mivel könnyen előfordulhat, hogy a több részre/tevékenységre való figyelés miatt a minőség rovására történik ez, és minden tevékenységben csak átlagosat nyújt majd a cég, mely messze nem kifizetődő egy globális piacon.

\section{EREDMÉNYEK}

Tehát az eddigiek alapján tudjuk, hogy a negyedik ipari forradalom a vállalatban használt eszközök összekapcsoltságát jelentik. A szolgáltatásokba és termékekbe integrált informatika, a gyártási környezethez automatikusan alkalmazkodó robotika jelenti az igazi újítást, továbbá az ezekhez megjelenő szolgáltatáscsomagok létrejötte. Az önmagában nem újítás a vállalat részéről, hogy adott vállalati területről minden információt tárolnak, ahogy az sem, hogy a felmerült hibákat folyamatosan orvosolják. Azonban ezeknek az információknak a birtokában, az azonnali reagálás képességével és egy megfelelően múködő gyártási-felügyeleti rendszerrel, valamint egy vállalatirányítási szoftverrel új alapokra helyezhető üzleti folyamat és üzleti modell valósulhat meg, melyet Bharadwaj társaival ${ }^{38}$ is vizsgált.

38 BHARADWAJ ET. AL. 2013. 471.o. 
A tanulmány termelékenység-vizsgálatát nehezíti az a tény, hogy egyegy ilyen hatásnak az eredményét egzakt módon rendkívül nehéz mérni. Egy termék-szolgáltatás előállítása során számos tényező szerepet játszik, melyeknek együttesen kell összhangban lenniük a termelékenység növekedése érdekében.

A negyedik ipari forradalom termelékenységre gyakorolt hatásának vizsgálatával Szalavetz ${ }^{39}$ is foglalkozott. Az „innovációs gazdaságtan” problémája az, hogy a technológiai fejlődés és a termelékenység növekedése között az összefüggés ambivalens. Nehéz a viszonyítási alap megválasztása, hiszen a negyedik ipari forradalmi vívmányok és a digitalizációs fejlődések nem egyszerre jelentkeznek, hanem több éves átfutási ciklusuk van, melyek az évek folyamán épülnek be szervesen az adott vállalkozási üzletmenetben is jól hasznosítható formában. Továbbá ez idő alatt a kezdeti hasznosíthatóságuk szélesedik, így nem lehet egy adott terület vizsgálatára lehatárolni az eredményeket. Ennek okán időben csak jóval később lehet releváns eredményeket is bemutatni, azonban bizonyos cégek már közölnek írásbeli tapasztalatokat, hogy milyen termelékenységnövekedéssel, költségcsökkenéssel találkoztak az üzletmenetük során.

A teljesség igénye nélkül számos egyén foglalkozott az ipari forradalom gazdasági kérdéseivel. Capgemini ${ }^{40}$, Fitzgerald és társai ${ }^{41}$, Burmeister $^{42}$, akik az ipari forradalom általános hatásait írták le, nem pedig egy-egy iparágra vonatkozó elképzeléseiket. Véleményük szerint globális szinten mérhető anyag- és energiamegtakarítás lesz mérhető, ami előrevetíti, hogy ugyan annyi termék és szolgáltatás előallítása kevesebb erőforrással is megoldható lesz. A speciális eszközök előállítása, javítása, karbantartása mind-mind könnyebbé válik a 3D nyomtatás technológiájának köszönhetően, hiszen az a vállalat, mely rendelkezik egy ilyen jellegű eszközzel, képes a saját igényeinek megfelelően az adott eszközt előállítani. Véleményem szerint egy jelenleg például autószerelő múhellyel, vagy műszaki termékek javításával foglalkozó cégek a termelékenységüket és a hatékonyságukat ennek köszönhetôen ugrásszerūen növelni tudják.

Petric és Simpson ${ }^{43}$ egy teljesen új digitális új-hullámról beszél a karbantartás modernizációjával kapcsolatban, mely a felszabaduló

\footnotetext{
${ }^{39}$ SZALAVETZ, 2011. 460.o.

40 CAPGEMINI, 2015.

${ }^{41}$ FitZGERALD ET. AL. 2013.

42 Burmeister - LueTtGgens - PiLler, 2015.

43 PETRICK - SIMPSON, 2013. 12.o.
} 
erőforrások hatására termékinnovációt eredményezhet. Példának említi a 3D modellezés és nyomtatás során, hogy ami eddig több alkatrészből állt, és csavarokkal, hegesztésekkel került összeillesztésre, a nyomtatás hatására egyben készre gyártható. A vállalat szempontjából óriási méretgazdaságossági korlát minimalizálást jelenthet, sốt más vállalatok számára a belépési korlátok teljes törlését is akár.

Az információs rendszerek folyamatos adatmentése és a mesterséges intelligencia adatelemzésének köszönhetően élő adatokat láthatnak a vállalati menedzsment emberei. Ennek köszönhetően pontosabban, gyorsabban képesek a stratégiai céloknak megfelelő döntéseket hozni, így megnyílhatnak új üzleti irányok is, melyek új bevételi forrásokat is generálhatnak, ugyan annyi, vagy közel annyi erőforrásra.

Teece $^{44}$ szerint egy esetleges új ipari-információs irány hatására új vállalati üzleti modellek is megvalósulhatnak, melyek eddig nem is léteztek. A hatására sokkal több fogyasztót meg lehet találni és meg lehet tartani, így több bevételre, nagyobb termelékenységre szert tenni. Véleménye szerint a legfontosabb, hogy a végtermékről kell igazán sok adatot gyűjteni, és nem a termelésről. A termelési adatok elemzése a szűk keresztmetszetek feltérképezésére valók, de az igazi adatok a végtermék felhasználói oldali elemzése. A vevőelégedettség a kulcsa a termelékenységnek. A negyedik ipari forradalom, pedig pont ezt teszi lehetôvé, hogy a végtermék értékesítést követően is a gyártónak szolgáltasson adatot a termékek összekapcsolódásából eredeztetően.

44 TEECE, 2010. 172.o. 


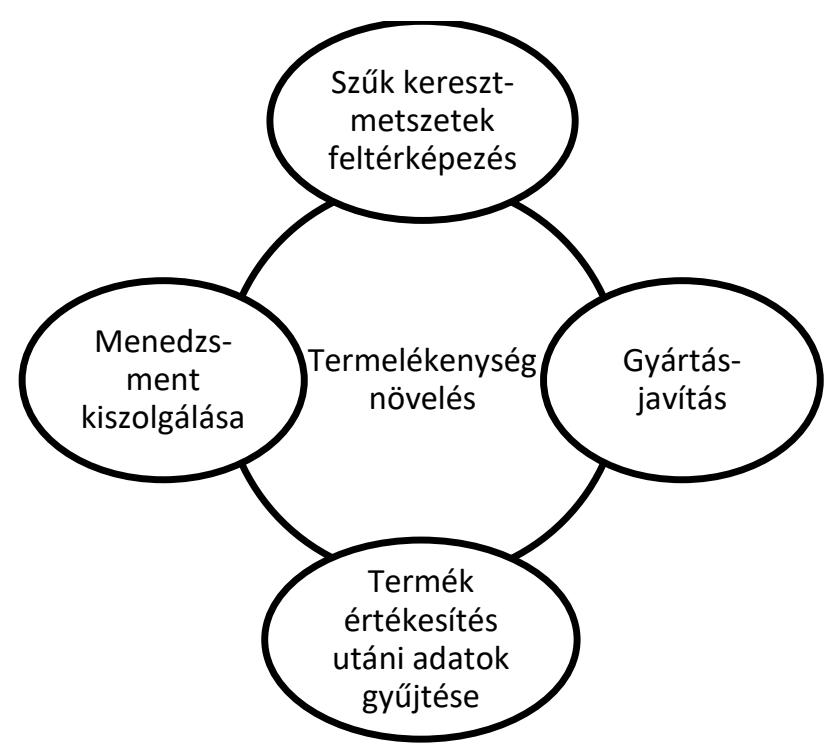

3. sz. ábra. Termelékenység növekedésének összetevői. Forrás: Saját szerkesztés Teece ${ }^{45}$; Petric és Simpson ${ }^{46}$ alapján.

\section{1. Állapot-felügyeleti eszközök, állapotfüggő karbantartás}

A kapcsolat a negyedik ipari forradalom és a termelékenység között négy kulcsterület között valósul meg. Schuh ${ }^{47}$ szerint ezek a területek az ITGloblizáció, az vállalatok valós adatainak rendelkezésre állása, automatizáció és a kooperáció. Ezek a területek együttesen a termelékenység növekedésébe hajtják a vállalatokat, nemzetgazdaságokat. Ezen tényezők fontosságát részletesen fogom bemutatni a következőkben.

Az IT területek elvitathatatlanul az utóbbi 15-20 év kulcspozícióját jelenti a vállalatok sikerességének. A számítási kapacitások hatalmas növekedése, a tárolási lehetőségek végtelen mérete, a szimulációk azonnali eredménye mind-mind a vállalat termelékenységének növekedésére mutatnak. A négy kulcsterület kapcsolata az IT rendszerekből indul. Ha feltételezzük, hogy egy adott cég adatainak jelentős részét már digitálisan tárolja, ott teszi elérhetôvé, továbbá tudjuk, hogy a vállalatirányítási

\footnotetext{
45 TeEce, 2010. 172.o.

${ }^{46}$ PetRICK - Simpson, 2013. 12.o.

${ }^{47}$ SCHUH, 2013. 25.o.
} 
rendszerekben közölt adatok a vállalatok valós adott időpillanatban érvényes adatait mutatják, akkor a digitális térben lehetőség van a menedzsment elképzelései alapján szimulációkat készíteni. Ezen szimulációk gyakorlatilag bármennyiszer futtathatóak és átalakíthatóak a számítókapacitás növekedése miatt. Lehetőség van arra, hogy a jövőben várhatóan bekövetkező eseményekre a vállalat felkészüljön. Ehhez szükség van a vállalaton belüli különböző területek együttmûködésére és a megfelelő folyamatok automatizálására.

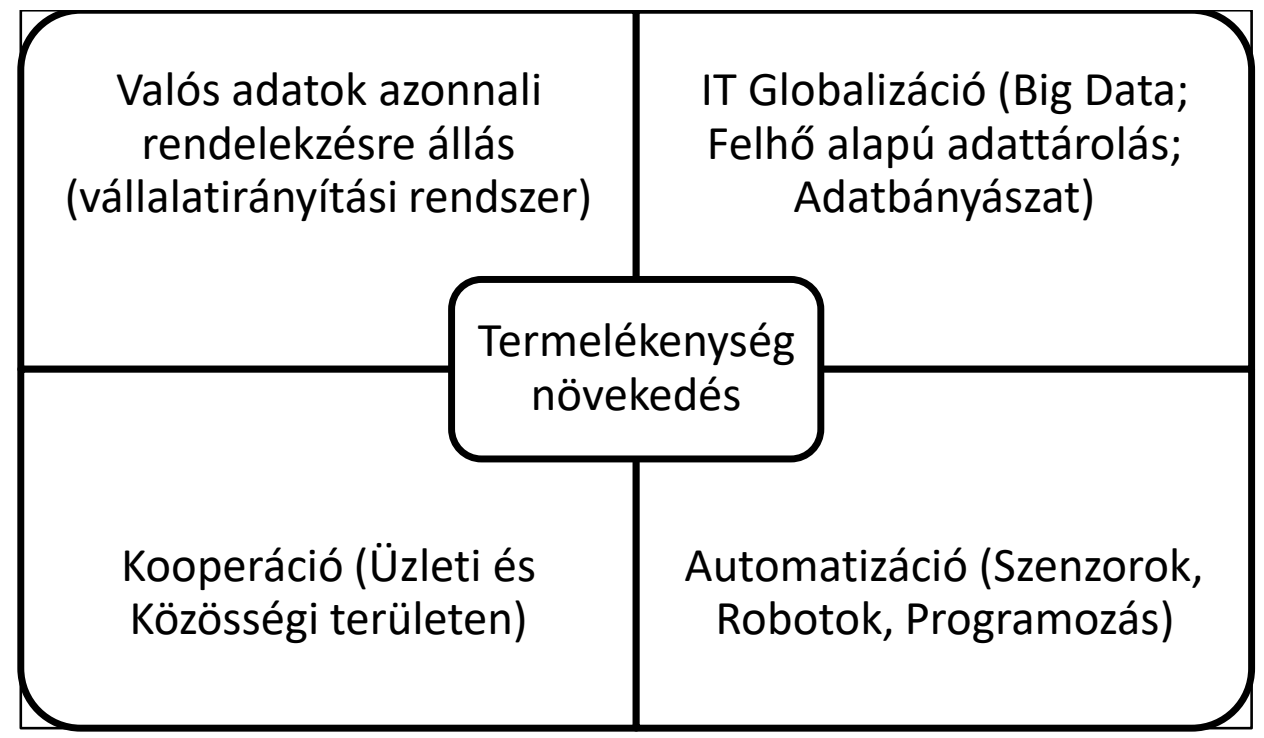

4. sz. ábra. Termelékenység növekedés pillérei. Forrás: Saját szerkesztés.

Az ábra a korábban leírtakat mutatja meg összefoglalva, lényege a folyamatos élő összekapcsolt rendszer és az állandó adatmegosztás. A vállalat megfelelő kulcstényezők birtokában képes arra, hogy a termelékenységét a megfelelő szintre emelje. Az ábra érdekessége továbbá az, hogy a vállalati oldalról mind a fizikai és IT oldalt, valamint a szoftver és hardwer oldalt is igénybe veszi a sikeresség érdekében. Tehát nem lehet csupán a negyedik ipari forradalomnak a technológiai vívmányaitól a termelékenység növekedést várni, hanem szükséges hozzá befektetett munkaóra is. Erre egyébként Autor ${ }^{48}$ is részletesebben ír tanulmányában, hogy a jövô a vállalatok számára a digitalizáció, de ehhez tenni kell, mert

48 AUTOR, 2015.o. 
csupán az újításoktól nem lesz jobb a vállalat, csak ha azokat bedolgozza és alkalmazza.

Brettel és társai ${ }^{49}$, valamint Fitzgerald és társai ${ }^{50}$ szerint a digitalizáció nem önmagában, hanem egy újfajta szolgáltatás-megközelítésben képes a termelékenységen javítani. Ez azt jelenti, hogy az eddig megszokott kereskedelmi alapú modelleket folyamatosan átformálódnak rendelkezésre állású modellé. Ezek egy újfajta megközelítést adnak a termelő vállalatok számára, mely a digitalizációs és negyedik ipari forradalom eredményeképpen születtek meg. A rendelkezésre állás egy olyan szolgáltatási modell, melyben a szolgáltató kötelezi magát, hogy a szerződésben megállapított berendezések üzemképesek lesznek, és annak termelő képességét fenntartják. Ehhez szükséges, hogy a szolgáltató gépeire a felhasználó érzékelőket szereljen. Az érzékelőket a szolgáltató folyamatosan figyeli, és gyanús visszajelzések során azonnal kivizsgálja a berendezést. Ezzel lehetőség nyílik arra, hogy nem akkor derül ki a hiba, amikor a gép meghibásodott, hanem menet közben korábban, kevesebb ráfordítással lesz a hiba elhárítva.

Az új ipari forradalom az adatmegosztásra és az azonnali elérhetőségre épül. Ez az ellátási lánc szintjéig hatol be. A cégek a beszállítókkal szorosan együttműködnek, és a termelékenység növekedésének a kulcsa ebben rejlik. A közös adatmegosztás mindkét fél részére előnyös, így együttesen tudnak a költségek ellen dolgozni a vállalatban. Az állapotfelügyeleti eszközök a negyedik ipari forradalom győztesei. Az SKF szerint azok a cégek, melyek hajlandóak bizonyos adatokat a szállitóikkal megosztani, és képesek a közösségi munka egy új szintjére lépni, a digitalizációban rejlő lehetőségeket ôk fogják először learatni.

A továbbiakban a vállalati termelékenység növekedés és az állapotfelügyeleti rendszerek közötti összefüggést vizsgálom. A negyedik ipari forradalom jelentô újításai megvalósították azt, hogy a hatalmas adattár, mely egy vállalkozás múködése során képződik, felhasználható, gyorsan elemezhető legyen. Ennek egyik eredménye lett a karbantartó területek rohamos fejlődése.

Tokutaro $^{51}$ és Davies ${ }^{52}$ már évekkel ezelőtt megfogalmazták, hogy miért is kulcsterület a vállalkozás szempontjából a gépek megfelelő

\footnotetext{
49 BRETTEL ET. AL., 2014. 37.o.

${ }^{50}$ FitZGERALD ET. AL., 2013.

51 TOKUTARO, 1994.
} 
működése. A tanulmányaik során bemutatták, hogy a karbantartási folyamatnak számos vállalati területen meg kell felelnie. Mindegy egyes vállalati rész (raktár, beszerzés, menedzsment, jogszabályi megfelelés) önmagában az eszközök szempontjából külön tervezést, irányítást, felügyeletet kíván, melyet minden napon az eszközök múködése során folyamatosan el kell végezni. Az állapotfigyelő és karbantartás felügyelő rendszerek ezt a folyamatot segíti gyorsabban és hatékonyabban elvezni. A 2010-es évek elején Shing ${ }^{53}$ tanulmánya alapján a karbantartásra a cégvezetôk úgy gondoltak mind egy újabb kiadásra, mely a cég hírnevét rombolja abban az esetben, hogy ha az átlagostól több. Valamint a magas karbantartási költség egyenlő a rossz gyárral, régi gépekkel. Azonban a 2015ös évtől kezdődően elindult egy stratégiai szemléletváltás az ipari forradalom hatására, mely azt hozta magával, hogy mi lenne, ha a karbantartási költségek meg se jelennének. El kell kezdeni előre látni és megpróbálni a hibát a felmerülése előtt kezelni. Ez a fajta szemléletmód és a digitális lehetőségek engedték meg, hogy az állapotfigyelő-szolgáltatás, karbantartásrendszerek kialakuljanak. Ez a stratégia lehetőséget teremt, hogy az eszköz értékét megőrizzük, csökkentsük az értékcsökkentést, növelje a funkcionális kihasználtsági rátát és ezáltal új értéknövelő beruházások biztos alapjaként szolgáljon.

$\mathrm{Az}$ állapotfelügyeleti rendszerek múködése nem bonyolult, melyet a következő ábra szemléltet.

${ }^{52}$ Davies, 2015. Industry 4.0: Digitalisation for productivity and growth

${ }^{53}$ Shing - Jun, 2015. 119. old. 


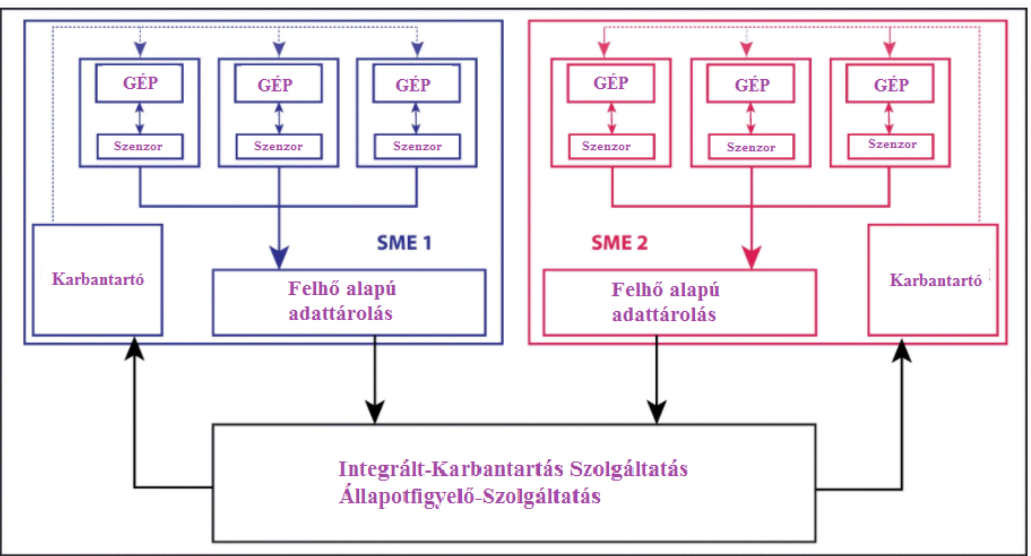

5. sz. ábra. Állapotfelügyeleti-rendszerek múködési logikája. Forrás: Kwaku és társai. ${ }^{54}$

A múködésének a lényege, hogy a gépekre szenzorokat kell csatlakoztatni, melynek eredményeképpen a működés minden időpillanatában adatok érkeznek a megfelelő felhő alapú tárhelyre. A vállalati rendszerbe integrált karbantartási szoftver, másnéven állapotfigyelőszolgáltatás a felhő alapú tárhelyre csatlakozva az adatokat folyamatosan elemzi. Az elemzés során hibákra, hibákat megelőző tendenciákra utaló jeleket keres. Találat esetén a karbantartót értesítve jelzi, hogy melyik gép várhatóan milyen hibát fog generálni. Ennek hatására a hibára előre fel lehet készülni, időben lehet megelőzni.

A Six Sigma ${ }^{55}$ elemzése megmutatta, hogy egy olyan szoftver a munkaerő hatékonyabb felhasználásától kezdődően, a folyamatok automatizálása, megbízhatóság növelése, raktár-monitoring, leállás-figyelő, termelékenység növelő, költség-csökkentés, berendezés élettartam növelés mellett a karbantartás jobb ütemezése, tervezése szempontjából is hatékonyabb.

Xue $^{56}$ tanulmányában a raktárkészlet és a karbantartás hatékonyabbá tételével foglalkozik. Az karbantartás-figyelő rendszerek pontos nyilvántartást vezetnek a raktár készletekről, amik a vállalati ERP rendszerekkel vannak összeköttetésben. Így jelentős pénzösszeget takarítanak meg a felesleges beszerzésekkel kapcsolatosan. A karbantartás

\footnotetext{
${ }^{54}$ KWAKU - ASHRAF - MUKUND, 2019. 3567.o.

55 SIX Sigma, 2020.

56 XUE, 2020.
} 
ciklusidejének és a hibatrendek alakulását is számítja és nyomon követi a rendszer, melynek hatására a karbantartás előre tervezhetôsége is pontosabb, továbbá a váratlan leállások száma csökken, és az álló idő és redukálódik.

A kiszámíthatóság Erdei ${ }^{57}$ szerint egy hosszabb távon biztosabb tervezést és szabályozottabb működést vetít előre, melyben a költségek egy előre tervezhető karbantartási ciklusban mozognak, nem pedig a gépek váratlan meghibásodásának függvényében.

Huber és társai ${ }^{58}$ valamint Zoltán ${ }^{59}$ tanulmányukban kiemelik, hogy a vállalkozás múködése során fontos, hogy minden rendelkezésre álló dolgot mérjünk. Mert az állapotfigyelő rendszerek, és a karbantartás-szolgáltatások csak ezek alapján képesek előre jelezni. Fontos, hogy a hagyományos eszközmenedzsmenti mutatószámok, eszközalapú megtérülések mellett a gépleállásokra, álló órákra, megelőző karbantartásokra, raktárkészletre, „,időben végzett karbantartásra” külön mutatószámokat kell a vállalkozásnak készítenie, hogy számszakilag is pontosan láthatóvá váljon, egy ilyen rendszere milyen segítséget nyújt. Továbbá olyan újfajta teljesítmény mutatók is kellenek, melyek mutatják, hogy a vállalkozás fejlődött. Ez a visszacsatolások miatt szükséges. Az állapotfigyelő, karbantartás-szolgáltatás használata során pedig rendkívül fontos, hogy az üzleti folyamatokat mindenki ismerje. Pontos ismeret kell, hogy mely lépés, hogyan következik a másik után, milyen egymásra épülés van a termelési láncban.

Adódik a kérdés, hogy ha ilyen sokrétű a felhasználhatósága, akkor hogyan lehet az ilyen digitális újítást bevezetni a vállalkozás múködésébe. Mik szükségesek ahhoz, hogy ez az implementáció sikeres legyen? Heppleman $^{60}$ szerint a sikeresség kulcsa az előrelátás. Pontosan meg kell tudni mondani előre, hogy mely területeken, miért szeretnénk ezt a figyelőszolgáltatást alkalmazni. Szükséges egy eredmény-idő-ráfordítás-beszerzésforrás-kommunikáció-implementáció mátrix felvázolása. Ezen vezérfonal mentén meg kell határozni, hogy pontosan milyen eredményt várunk el a bevezetéstől, és milyen feltételek esetén tekintjük sikeresnek a bevezetést. Fontos, hogy a bevezetés során egy pontos idő-költség terv is kialakításra kerüljön, melynek során az egyes implementációs lépésekhez hozzárendeljük, hogy mennyi idő alatt, milyen költség mellett tudjuk az a

\footnotetext{
${ }^{57}$ ERDEI, 1992. 131.o.

${ }^{58}$ HuBER ET. AL.,2019. 904.o.

59 ZOLTÁN, 2016.

${ }^{60}$ HeppelmanN, 2014. 64.o.
} 
szakaszt megvalósítani. Természetesen a költséghez meg kell határozni, hogy azt a vállalkozás hogyan szeretné biztosítani. Saját bevételéből fedezi a kiadásokat, vagy esetleg valamilyen pályázat, támogatás esetleg hitel terhére. Végezetül a vállalat munkavállalói részére a megfelelő kommunikáció lefolytatása is fontos, melyben tájékoztatják őket, hogy milyen új beruházás került megvalósításra, és ez a munkájukra milyen hatást fog gyakorolni.

Egy ilyen bevezetés sikeressége számos módon lemérhető véleményem szerint. Milyen mértékben használják a vállalkozás területein. Hogyan épül be ez a folyamatokba, mennyire függenek tőle a termelési lépések. Terveznek-e vele a vállalkozás éves költségvetésében. Egy ilyen bevezetés Crnjac és társai ${ }^{61}$ szerint akkor sikeres, hogy a 6 . hónaptól legalább 36 hónapon át szignifikánsan magasabb ROI értéket érnek el, mint a bevezetés előtt. Továbbá, ha a teljes karbantartási költség közel 40\%-kal csökkennek, és a raktározási anyagköltségek 30\%-kal esnek vissza. Azonban Huber és társai egy kaliforniai olajtársaság adatai alapján - akik már ilyen digitális rendszert használnak - arra a megállapításra jutottak, hogy az élőmunka ráfordítása közel 20\%-kal, a leállások száma szintén 20\%-kal, a raktárkészlet és a hozzá tartozó raktározási költség 34\%-kal a váratlan leállások 92\%-kal, a karbantartási költségek 40\%-kal csökkentek. Továbbá a berendezések élettartama 10\%-kal, a hatékonyságuk 133\%-kal, a teljes üzem termelékenysége 35\%-kal növekedett.

Lashi és társai ${ }^{62}$ valamint Niyue $^{63}$ kutatásuk alapján megállapították, hogy Németországban az éves karbantartási költség megközelítőleg 250 milliárd eurónak megfelelő összeg. Ebből következőleg a legnagyobb hatékonyság és termelékenység javulás evidensen a legnagyobb költség csökkentésével lehetséges. Ez azt jelenti, hogy egy vállalkozás számára az egyik legfontosabb tétel a karbantartási költségek csökkentése. A Machine Metrics ${ }^{64}$ tanulmánya alapján egy-egy ilyen szolgáltatás rendszer múködése során 10-40\% közötti a karbantartási költségek csökkenéssel, 10-20\% közötti a hulladék csökkenéssel és 10-50\% közötti a gépek új értéknövelő beruházásának lehetőségével kell kalkulálni. Ugyan ilyen elemzést a Delloite $^{65}$ cég is végzett, melyben megállapították, hogy 5-10\% közötti anyagköltség, 10-20\% gépi eszközérték, 5-10\% alap karbantartási költség,

${ }^{61}$ CRNJAC - VEŽA - BANDUKA, 2017. 21.o.

${ }^{62}$ LASI ET. AL., 2014.

${ }^{63}$ NIYUE, 2013. 60.o.

${ }^{64}$ Machine Metrics, 2018.

${ }^{65}$ DeloitTe, 2017. 
20-50\% gépi álló idő megtakarítással reális lehet. Továbbá a tanulmányok ugyan nem szólnak róla, de a raktározási költségekre is gondolni kell, mely szintén jelentős mértékű forrást igényel, amennyiben nem megfelelő módon történik a készletezés rendszerezése.

A karbantartási állapotfigyelő-szolgáltatás a vállalkozás OEE (angol elnevezéssel: Overall Equipment Effectiveness - berendezéshatékonyság) mutatószámára gyakorol hatást. A kontrollingban számos mutatószám épül a tárgyi eszközök köré. Hatékonyság, karbantartás, kapacitás, álló idő, elméleti termelékenység, gyakorlati hozam és még sok más. Azonban ezekben a mutatószámoknak - legalábbis a legtöbbnek - köze van a tárgyi eszköz karbantartásához. Vagy úgy, hogy amíg áll a gép meghibásodás miatt addig megmutatja, hogy mennyi terméket nem gyártott le, azaz milyen bevételkiesést okozott, vagy pedig oly módon, hogy amíg nem múködik a gép, milyen ráfordítás keletkezett a karbantartás miatt az álló idő közben. Tehát amíg egy termelő berendezés nem múködik, duplán okoz veszteséget a vállalkozás számára. Egyrészről nem készül el a termék, amiből bevétel lehetne, másrészről csak karbantartási kiadás keletkezik. A gépek állapotfigyelő-szolgáltatása pontosan ezt a váratlan álló időt jelzi előre, és ez eredményez termelékenység és hatékonyságnövekedést a vállalkozás során.

E rendszer használatával adódik, hogy egy új szemléletmód is kialakul a menedzsment számára, mely a vállalat stratégiai területére hat. A hosszú távú célok közé a gépekkel kapcsolatos tételek is felkerülnek, melyek között fontos rész-stratégiák alakulhatnak ki. Gépfenntartási stratégia, tervszerű megelőző karbantartás, prediktív karbantartás, tudás alapú karbantartás, kockázat alapú karbantartás. A stratégiák alakulása véleményem szerint az iparágtól függ. Továbbá figyelembe kell venni, hogy milyen a gépek szerkezete, tömegtermelésre vagy egyedi megrendelésre gyárt a vállalkozás.

Az állapotfüggő-karbantartás és a karbantartás előrejelzés lehetőséget ad a vállalkozások számára, hogy Seiichi Nakajima által kitalált teljes körű hatékony karbantartás elvét megvalósítsa. Seiichi ${ }^{66}$ elmélete az volt, hogy egy olyan karbantartás filozófiát alakít ki, mely a vállalkozásnak a termelékenységére hat közvetlenül. Sajnos a kitalált koncepció a gyakorlatban olyan nehezen megvalósítható, hogy csak részterületek kerültek a korábbi évekig megvalósításra. A stratégiai koncepció lényege, hogy a termelékenységet úgy próbálja meg növelni, hogy a berendezések hatékonyságát - álló idő csökkentés - maximalizálni próbálja, továbbá teljes

${ }^{66}$ SEIICHI, 1988. 
élettartamra folyamatos karbantartási fenntartó rendszert alakítana ki, a berendezés tervezőjétől, karbantartóján át a gép használójáig mindenkit bevonva a fenntartásba. A vállalkozások számára ez roppant sok adatot és időt igényelt volna, mígnem az állapotfigyelő-rendszerek a folyamatos elemzési és adatszolgáltatási képességükkel ezt az elméleti stratégiát megvalósították. Olyan szinten lehetett sikerrel alkalmazni, hogy ezt a koncepciót a termelési gépekről kiterjesztették az értékesítésben, adminisztrációban lévő gépekre is. Seiichi ${ }^{67}$ évekkel ezelőtti elméleti eredményei azt mutatják, hogy a gépek ilyen módon történő karbantartásával a kapacitásnövekedés közel 50\%-os, a minőségjavulás is közel 50\%-os, a karbantartási költségek közel 40-50\%-kal csökkennének és a karbantartási munkaigény pedig 60\%-kal emelkedne. A tanulmány nem számolt még a digitalizációs eredményekkel, miszerint a munkaigény a folyamatos gépellenőrzést és adatszolgáltatást is magában foglalja. Természetesen a munkaigény mindenképpen nőne, azonban a karbantartásrendszer komoly mennyiségű munkát vállalna át a munkavállaló válláról. Braun $^{68}$, Tari ${ }^{69}$, Geroski $^{70}$ szerint a vállalatok stratégiáinak megváltoztatása komoly elköteleződést kíván a menedzsment részéről, és csak megfelelő eredmények birtokában van lehetôségek ezeket megtenni. Sajnos a pontos adatok egyenlőre külső vizsgálóknak csak a modellezések alapján ismeretesek, de a menedzsment részére pontos adatok biztosan birtokukban lesznek, hogy erre a stratégiai váltásra felkészüljenek.

\section{KONKLÚZIÓ}

Sajnos pontos számadatok nem állnak rendelkezésre arról, hogy azon kevés vállalkozás, melyek alkalmazzák ezt a rendszert, milyen költségmegtakarítással rendelkeznek. Azonban a tanulmányomban bemutatott eredmények jó közelítést adhatnak arra, hogy milyen jellegú és mértékű megtakarításokkal lehet számolni a használata során. Egyértelműen kijelenthető véleményem szerint, hogy a hatékonyság növekedése a költségek csökkentésével kezdődik, melyre kiváló szolgálatot tehet a karbantartás-felügyelő rendszer. Ha csak a tanulmányban is említett termelékenység alap tézisére az output - input hányadost figyeljük, és

\footnotetext{
${ }^{67}$ SEIICHI, 1988.

${ }^{68}$ BRAUN, 2013. 1.o.

${ }^{69}$ TARI, 1996. 363.o.

70 Geroski, 1993.
} 
feltételezzük, hogy a vállalkozás minden egyéb adata a karbantartás költségen kívüli változatlan, akkor komoly mértékű termelékenység javulást lehet elérni. Sajnos a számítás a pontos számadatok sok tényezőtől függenek, aminek az az eredménye, hogy egzakt módon egy adott változóra vetítve szinte lehetetlen a valós termelékenységet megmérni. A karbantartásszoftver hatására - mint a tanulmányban szó volt róla - a karbantartási költségek mellett a raktározási kiadások és a felhasznált munkaórák is változnak. Kevesebb álló idő több termék előállítását teszi lehetővé, ezáltal alapvetően növelve a termelékenységet. Azonban annak eredményét nehéz megjósolni, hogy a több termék több nettó árbevételt jelent-e. Ez más kutatási kérdést vet fel. Ahogy szintén külön vizsgálható a karbantartásfelügyelő rendszerrel kapcsolatban az említett újfajta stratégiai megközelítés az előrejelző-karbantartás. A tanulmány csak az alapvetően kevés egyéb tanulmányok és kutatási eredmények szintézisét mutatja be. Való életbeli adatok hiányában csak a tanulmányok eredményeire és becsléseire lehet alapozni, azonban azok rendkívül kecsegtetőek. Amennyiben több vállalat fogja bevezetni ezt a fajta digitális megoldást, minden bizonnyal több és pontosabb adatok állnak majd rendelkezésre. Az élő adatok folyamatos elemzése, szimulálása megteremti azt a lehetőséget, ami ahhoz szükséges, hogy előre lehessen jelezni a várható hibákat, előre fel lehessen készülni arra, így kisebb költséget okozzon a vállalkozásnak. A hibák elôrejelzése egy új stratégiai megközelítést is eredményez a menedzsment részére, mely azért fontos, mivel egy alapjaiban egy termelő tevékenységre berendezkedett cég esetén a karbantartás előrejelzése roppant sok kiadástól óvhatja meg a vállalkozást, ezáltal növelve a hatékonyságot és a termelékenységet. A hatékonyság és a termelékenység növekedése a vállalkozás bevételszerző képességére is hatást gyakorol. Esetlegesen új lehetőségeket is megnyithat egy-egy cég számára a nemzetközi piac felé is. A digitális újítások hatására számos átalakulás megy végbe, közöttük a nemzetközi szintéren is. A negyedik ipari forradalom hatására kialakult új rendszerek, megvalósuló azonnali gépi kommunikációk a nemzetközi gazdaságban is éreztetik hatásukat közvetve és közvetlenül. A vállalati menedzsmentnek tehát széles körben kell tisztában lennie azzal, hogy milyen újítások és lehetôségek vannak, melyet érdemes használni a sikeres belföldi és nemzetközi viszonylatban is. 
A negyedik ipari forradalom digitális újításai - Állapotfigyelő-karbantartó rendszerek hatása a termelékenységre

\section{FELHASZNÁLT IRODALOM}

ADEsINA, O. S. (2017): Foregin policy in an era of digital diplomacy; Cogent Social Sciences. DOI azonosító: https://doi.org/10.1080/23311886.2017.1297175

AuTOR, D.H. (2015): Why are there still so many jobs? The history and future of workplace automation. The Journal of Economic Perspectives, Vol. 29., No.

3. DOI azonosító: $10.1257 /$ jep.29.3.3

Beata S.,Manuel, T., Adnan, U. H., Judit, O. (2020): Predictors of industry 4.0 technologies affecting logistic enterprises' performance: international perspective from economic lens; Technological and Economic Development of Economy, Vol. 36. DOI azonosító: 10.3846/tede.2020.13376

Bharadwaj A., El Sawy O., Pavlou P., Venkatraman N. (2013): Digital business strategy: toward a next generation of insights; MIS Quarterly Vol. 37 No. 2, pp. 471-482

BRAUN R. (2013): A vállalatok politikája - vállalati, társadalmi felelősségvállalás, vállalati közösségek és a vállalati stratégia jövője Vezetéstudomány XLIV. évf. 1. szám p 1-28

Brettel, M., Friederichsen, N., Keller, M., Rosenberg, M. (2014): How virtualization, decentralization and network building change the manufacturing landscape: An Industry 4.0 Perspective. International Journal of Mechanical, Industrial Science and Engineering, Vol. 8., No. 1., 37-44. o

Burmeister, C., Luettgens, D., Piller, F.T. (2015): Business Model Innovation for Industriem 4.0: Why the "Industrial Internet" Mandates a New Perspective on Innovation. RWTH-TIM Working Paper, Aachen: RWTH, Elérhető: http://dx.doi.org/10.2139/ssrn.2571033

CAPGEMINI (2015): The digital advantage. How digital leaders outperform their peers in every industry. Elérhetô: https://www.capgeminiconsulting.com/the-digital-advantage letöltés ideje: 2021.01.20

Cohen, R. (1998): Putting diplomatic studies on the map. Diplomatic studies program newsletter. Leicester: Centre for the Study of Diplomacy

CHOU C. J. (2017): Essential implications of the digital transformation in industry 4.0, Journal of Scientific \& Industrial Research, Vol. 76, p. 465467

CrABB, JR. C. V. (1972). American foreign policy in the nuclear age (3rd ed.). New York, NY: Harper \& Row. 
CRnjaC M., VEŽA I., BANDUKA N. (2017): From concept to the introduction of Industry 4.0. International Journal of Industrial Engineering and Management. Vol. 8 p.21-30

CSEDÔ Z., MÁTÉ Z., SÁRA Z. (2019): Innováció-e a digitalizáció? A digitális transzformáció és innováció menedzsment tanulságai egy pénzügyi szolgáltatónál, Vezetéstudomány Évf. 50 szám 7 - 15 pp.

DAVIES R. (2015): Industry 4.0: Digitalisation for productivity and growth, http://www.europarl.europa.eu/RegData/etudes/BRIE/2015/568337/ EPRS_BRI568337_EN.pdf letöltés ideje: 2020.11.05

DeLoitTe (2017): Predictive maintenance and the smart factory; Deloitte Development LLC

ERDEI J. (1992): Az üzemeltetési megbizhatóság elemzése, Vezetéstudomány XXIII. évf. (1992/9-10 szám) 131-138

EY (2020): Digital Directions: A perspective on the impact of digital technologies, EYGM Limited

FEDER, G. (1982): 'On Exports and Economic Growth'. Journal of Development Economics 12: 59-73.

Fitzgerald, M., Kruschwitz, N., Bonnet, D., Welch, M. (2013): Embracing Digital Technology: A new strategic imperative. MIT Sloan Management Review Research Report, MIT

GAZDASÁgi VERSENYHIVATAL (2007), Verseny és termelékenység, Budapest

GEROsKI, P. A. (1993): A vállalatok közötti vertikális kapcsolatok és az iparpolitika. Vezetéstudomány, 12. sz.

GLAVANITS, J. (2018): A technológia alkalmazásának jogi előkérdései: a fogalmi keretek pontosításának szükségessége Jog Állam Politika: Jog- és Politikatudományi folyóirat, 10 (3). pp. 173-183

Hanson, F. (2012): Baked in and wired: eDiplomacy@State, Foreign Policy Paper Series no 30 (pp. 1-41), Washington, DC: Brookings Institution.

HePpeLmanN J. (2014): How smart, connected products are transforming competition: Spotlight on managing the Internet of Things. Harvard Business Review. Vol. 92 p. 64-88

Herterich, M. M., Uebernickel, F., \& Brenner, W. (2015): The Impact of Cyber-Physical Systems on Industrial Services in Manufacturing. 7th Industrial Product-Service Systems Conference - PSS, industry transformation for sustainability and business. Procedia CIRP 30, pp. 323 - 328. ELSEVIER. 
A negyedik ipari forradalom digitális újításai - Állapotfigyelő-karbantartó rendszerek hatása a termelékenységre

Huber J., Muller S., Fleischmann M., Stuckenschmidt H. (2019): A data-driven newsvendor problem: From data to decision. European Journal of Operational Research. Vol. 278 p. 904-915

INNOSIGHT (2020): Forecast: Creative Destruction is Accelerating, S\&P 500 lifespans continue to shrink, requiring new strategies for navigating creative destruction, Elérhető:

https://www.innosight.com/insight/creative-destruction/ (Letöltve: 2020.12.14.)

KAGERMANN H. (2013): Recommendations for Implementing the Strategic Initiativ, National Academy of Science and Engineering, Amsterdam

KERÉNYI, Á. (2017): A FinTech-jelenség hatása - Radikális változás zajlik a pénzügyi szektorban? Hitelintézeti Szemle, 16. évf. 3. szám 32-50

KINZEL H. (2019): Industry 4.0 - Where does this leave the Human Factor? Elérhetô:

https://www.researchgate.net/publication/308614137_Industry_40_W here_does_this_leave_the_Human_Factor letöltés ideje: 2020.12.15

KorNAI, J. (2015): Milyen is hát a tőke a 21. században? Közgazdasági Szemle, LXII. évf. 909-942

KusminM L. (2019): Industry 4.0, Information Society Approaches and ICT Processes, School of Digital Technologies, Tallinn University, Estonia

KWAKU A., Ashraf A., MuKUnd N. (2019): A predictive maintenance cost model for CNC SMEs in the era of industry 4.0 The International Journal of Advanced Manufacturing Technology volume 104, pages 3567-3587

Lasi H., Kemper H.G., FetTKe P., Feld T., Hoffmann M. (2014): Industry 4.0. Business \& Information Systems Engineering. Springer

LIU Q. (2016): A Categorical Framework of Manufacturing for Industry 4.0 and Beyond, Procedia CIRP Volume 52, 2016, Pages 173-178

MACHINE METRICS (2018): The impact of predictive maintenance on manufacturing. Elérhető: $\quad$ https://www.machinemetrics.com/blog/the-impact-ofpredictive-maintenance-on-manufacturing (Letöltve: 2021.02.11.)

MANOR, I., SEGEV, C. (2015): America's selfie: How the US portrays itself on its social media accounts. In C. Bjola \& M. Holmes (Eds.), Digital diplomacy: Theory and practice. New York, NY: Routledge.

MONOSTORI, L. (2015): Cyber-physical production systems: roots from manufacturing science and technology. at-Automatisierungstechnik, Vol. 63., No. 10. DOI azonosító: $\underline{\text { 10.1515/auto-2015-0066 }}$ 
Mugge P. (2017): The Gap Between the Practice and Theory of Digital Transformation, Whitepaper in: The 50th Hawaiian International Conference of System Science

NIYUE T. (2013): Securing the future of German manufacturing industry Recommendations for implementing the strategic initiative, INDUSTRIE 4.0, Federal Ministry of Education and Reasearch, Frankfurt pp. 60.

PETRICK, I.J., SIMPSON, T. W. (2013): 3D printing disrupts manufacturing: how economies of one create new rules of competition. Research-Technology

Management, Vol. 56., No. 6. DOI azonosító: https://doi.org/10.5437/08956308X5606193

PÖLÖS Zs. (2020): A koronavírus pozitiviv hatása: 6 émyit fejlödött a digitalizáció. Elérhető: https://trans.info/hu/a-koronavirus-pozitiv-hatasa-6-evnyitfejlodott-a-digitalizacio-194804 (Letöltve: 2020.01.04.)

SCHuH, A. (2013): Central and Eastern Europe After the Boom: Time for a Strategy Change for Foreign Multinational Companies?, Central European Business Review, Vol. 2., No. 2. DOI azonosító: 10.18267/i.cebr.43

SCHUMACHER W., SHIN A. (2016): A Maturity Model for Assessing Industry 4.0 Readiness and Maturity of Manufacturing Enterprises, Procedia, CIRP Volume 52,2016

SCHWAB K. (2016): The Fourth Industrial Revolution: what it means, how to respond Founder and Executive Chairman, World Economic Forum

SEIICHI N. (1988): Introduction to TPM: Total Productive Maintenance (Preventative Maintenance Series) Productivity Pr Japan

ShInG, J.-H. Jun, H.-B (2015): On Conditionbased Maintenance Policy. Journal of Computational Design and Engineering, 2.

SIX SIGMA (2020): Számitógépes karbantartás-menedzsment rendszerek (CMMS) Elérhető:

http://www.sixsigma.hu/sites/default/files/publikacio/CMMS $\% 20 \mathrm{FA}$ A.pdf (Letöltve: 2021.01.14.)

SzALAVETZ, A. (2011): Innovációvezérelt növekedés? Közgazdasági Szemle, 58. évf., 5. szám

SzŰCS S. (2011): A sqüleséges rossz, mint jó befektetés. Karbantartás minőségirányításának feladata, Economica IV. évf. 10. sz.

TARI E. (1996) Vállalti stratégiák, Közgazdasági Szemle XLIII évf. 4. szám TEECE, D. J. (2010): Business models, business strategy and innovation. Long Range Planning, Vol. 43., No. 2. DOI azonosító: https://doi.org/10.1016/j.lrp.2009.07.003

Tokutaro S. (1994): TPM in Process Industries, Gulf Publishing Company 
VÁncza, J., Monostori, L., Lutters, D., Kumara, S. R., Tseng, M., VAlCKenaers, P., VAN Brussel, H. (2011): Cooperative and responsive manufacturing enterprises. CIRP AnnalsManufacturing Technology, Vol. 60., No. 2. DOI azonosító: https://doi.org/10.1016/i.cirp.2011.05.009

WANG Q. (2016): Industrial water pollution, water environment treatment, and health risks in China in Industry 4.0. Environmental Pollution Volume 218, November 2016. DOI azonosító: 10.1016/j.envpol.2016.07.011.

WORLD ROBOTICS (2020): IFR presents World Robotics Report 2020 Elérhető: https://ifr.org/ifr-press-releases/news/record-2.7-million-robots-workin-factories-around-the-globe (Letöltve: 2021.01.15.)

XuE-Ming Y. (2020): Impact of Industry 4.0 in Inventory Systems and Optimization, Impact on Intelligent Logistics and Manufacturing Vol. 4. DOI azonosító: $10.5772 /$ intechopen.90077

Zhaofang C., Lele Z., Guangdong T. (2020): Economic Maintenance Planning of Complex Systems Based on Discrete Artificial Bee Colony Algorithm; IEEE Acces, Quality Technology \& Quantitave Management, Vol. 8. DOI azonosító: 10.1109/ACCESS.2020.2999601

ZOLTÁN Z. (2016): A kontrolling fejlödéstörténetének föbb irányzatai, Gazdaság \& Társadalom Journal of Economy \& Society Vol 2. 